\title{
RELIGIOUS EDUCATION IN THE PUBLIC SPHERE IN SLOVENIA
}

\section{Frane STANIČIĆ ${ }^{1}$}

Slovenia is among the few European states that explicitly do not allow religious education in public schools. This rule is prescribed by the Organization and Financing of Upbringing and Education Act (Education Act), which explicitly prohibits all religious activities in public schools. It prohibits any other kind of denominational activity in public schools and kindergartens. Several Slovene authors have argued that the area of education runs a high risk of either remaining or becoming a battlefield for ideological disputes. This study analyses the Slovenian legal regulation of religious education in public schools. First, the Slovenian model of state-church relations is explained. Then, a brief overview of the historical regulation of religious education in Slovenia's public schools is provided in order to enable a clear understanding of current regulations.

\begin{tabular}{l|l} 
religion \\
religious education \\
relovenia \\
Sublic school \\
pul
\end{tabular}

\section{Introduction ${ }^{2}$}

One cannot overstress the importance of schools and education. Schools are one of the main mechanisms of socialisation. Schools exist in specific social and historical contexts, which mark them significantly. Educational programs are determined not only by the general results of the development of basic human knowledge but also by the tradition and culture of a particular society. ${ }^{3}$ Most European countries provide religious

1 | Associate Professor, Faculty of Law, University of Zagreb, Croatia, frane.stanicic@pravo.hr, ORCID: 0000-0001-8304-7901,

2 I I am using parts of my paper "Religious Symbols in the Public Sphere in the Legal Order in Slovenia" (in print) in this paper.

3 | Marinović Bobinac, 2007, p. 426.

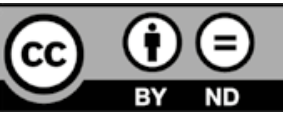


education. ${ }^{4}$ Religious educational content is conveyed in one of the following ways: as confessional religious education, as non-confessional religious education delivered as a separate subject, or as non-confessional religious education delivered as part of other subjects. ${ }^{5}$ Religious education is sometimes a hotly disputed issue. As Ivanc states, the area of education runs a high risk of either remaining or becoming a battlefield for ideological disputes. ${ }^{6}$ Slovenia is among the few European states that provide no official religious education in public schools. However, one elective (obligatory) course, Religion and Ethics (Varstva in etika), is taught in senior primary school. It is interesting to mention that the Organisation and Financing of Upbringing and Education Act (Education Act) ${ }^{7}$ explicitly prohibits any religious activities in public schools. It also prohibits any other kind of denominational activity in public schools and kindergartens. This is why some scholars see an equation between Slovenia and France regarding religious education. ${ }^{8}$ It is thus worthwhile analysing the legal regulation of religious education in Slovenian public schools (which differs from the regulation of private schools).

\section{Historical development}

Before the Second World War, religious instruction in Slovenia was not only obligatory in public school but it was also regarded as the basis and crowning glory of public education. ${ }^{9}$ Historically, the Catholic Church and the Evangelical Church of the Augsburg Confession made important historical contributions to the development of the schooling

4 | It is the aim of confessional religious education to promote an obligation towards a particular religion. In most developed European countries, there is an awareness of the difference between religious education as part of education in schools and religious education in church. In accordance with this awareness, the confessional approach to religious education has shifted in many countries from pursuing catechetic (growing in faith), formative, pastoral, and evangelic aims towards educational and intercultural aims, to offer civic education and education for peace and tolerance. The aim of non-confessional religious education is to transfer information about religion/religions to develop social tolerance and provide students with a view of different religions and worldviews, allowing them to make a conscious choice and live in a pluralist society. Ideally, religions are discussed neutrally, objectively and harmoniously; ibid.

5 | Ibid. Most European countries provide confessional religious education in public schools (e.g. Belgium, Bosnia \& Herzegovina, Germany, Finland, Croatia, Luxembourg, Latvia, Lithuania, Austria, Poland, Portugal, Serbia, Slovakia, Spain, Greece, Ireland, Italy, Malta, Romania). Some offer religious education outside of the public school system, but on public school premises (e.g. Moldavia, Chech Republic, Hungary). Some countries provide religious education in the form of religious culture (e.g. Denmark, Estonia, Island, Great Britain, Holland, Norway, some Swiss cantons, Sweden, Ukraine). Only three European countries do not provide religious education in any form: France (with the historically conditioned exceptions of Alsace and Mosele), Albania, and Slovenia; see Filipović, 2011, p. 140; Staničić, 2018, p. 402.

6| Ivanc, 2015, p. 137.

7 | Uradni list RS, no. 16/07 (consolidated text), 36/08, 58/09, 64/09, 65/09, 20/11, 40/12, 57/12, 47/15, $46 / 16,49 / 16,25 / 17,123 / 21$.

8 | Education about religion at public schools in Slovenia is, from a legal point of view, similar to that in France and different from that in most European countries, where the laws guarantee religious instruction within the framework of the public school; Kodelja, 1999, p. 153.

9 | Ibid. 
system in Slovenia. ${ }^{10}$ In the Austro-Hungarian Empire and the subsequent Kingdom of Yugoslavia, religious communities had a strong influence on education. Religious education was an obligatory subject, and religious communities had the exclusive right to implement it.11 The Catholic Church enjoyed a privileged position, especially in the Austro-Hungarian Empire. ${ }^{12}$

The political transformations that occurred at the end of the Second World War and the creation of a new socialist Yugoslavia within the new European cuius regio, eius religio determined at Yalta in February 1945 might be considered the realisation of the possibilities David Martin attributes to the Latin (and partly the Orthodox) pattern: Given suitable historical circumstances, polarisation can develop into a conflict of vicious dimensions. According to Martin, such a confrontation may result in either a strengthened rightist pro-Church authoritarian regime or a leftist anti-clerical authoritarian regime. Precipitated by the Second World War, the second option prevailed in Slovenia, and a conflict pattern of social secularisation was established. ${ }^{13}$ In this system, the separation of church and state could not have been neutral. ${ }^{14}$ Communist Yugoslavia introduced a strict separation of church and state, an atheistic and materialistic ideology based on Marxism, and a systematic and constant oppression of religion and believers. ${ }^{15}$ Therefore, throughout the communist era, religious education was banned from public schools (as was religion from the public sphere). ${ }^{16}$ After 1952, religious education was completely banned. ${ }^{17}$

After 1991, the democratic Republic of Slovenia enacted a new constitution, which marked a departure from the negative perception of religion and initiated a search for new foundations for the church-state relationship. ${ }^{18}$ However, Slovenia took a path different from that of most of the former Yugoslav republics, which opted for a separation of church and state but with strong ties with whatever was the most numerous religious community (the Catholic Church in Croatia, the Serbian Orthodox Church in Serbia, Islam in Bosnia). Slovenia envisaged its own state-church relations model, which can be linked to the well-known French model of laicite, although it is not legally prescribed as such. The preamble of the 1991 Constitution of the Republic of Slovenia contains no reference to God or religion. Article 7 of the new democratic constitution defined the

10 | Ivanc, 2015, p. 137.

11 | Staničić, 2014, p. 230.

12 | Smrke, Rakar, 2006, p. 11.

13 | Črnić et al., 2013, p. 210.

14 | Ibid.

15 | Ivanc, 2015, p. 138.

16 In 1945, the government prohibited the operation of any kind of private school, and many private schools that operated before this time were nationalised. Religious communities could establish religious schools only to educate priests, and diplomas from these religious schools were not publicly recognized. As a result, the atheism prescribed by Marxism was the privileged belief in Slovenia for almost half a century and was encouraged throughout the educational system (Šturm, 2004, p. 610). Today, Article 57 provides for freedom of education, which is closely related to the rights of peaceful assembly and the freedom of association. In guaranteeing freedom of education, Article 57 also prescribes compulsory elementary education financed from public funds. The 1991 Constitution provides for the autonomy of public universities and other public junior colleges; however, it leaves regulation over the manner of their financing up to statutes. Thus, while the 1991 Constitution does not explicitly provide for religious schools, the constitutional right to freedom of education seems to permit them; ibid., p. 615.

17 | Smrke, Rakar, 2006, p. 11.

18 | Ivanc, Šturm, 2015, p. 379. 
role of churches and religious communities and their relation to the state. Article 7 sets forth the following basic principles: separation between the state and religious communities, equality among religious communities, and the free activity (autonomy) of churches and religious communities within the legal order. ${ }^{19}$ When Slovenia declared independence from Yugoslavia in 1991, the new state initially decided not to regulate the relationship between public schools and religion (i.e. the Roman Catholic Church, with which the majority of Slovenes affiliate), especially since restrictive regulation could paradoxically provoke new problems. ${ }^{20}$ Since 1991, the religious composition of Slovene society has gradually changed, becoming slightly more diverse, and the Ministry of Education has started receiving requests from school principals to advise them on how to act in concrete cases of (non-Christian) religious symbols entering school spaces. Meanwhile, the pressure exerted by the Catholic Church for a more visible presence in schools has not abated. ${ }^{21}$ Recognising the need ${ }^{22}$ to revise its initial decision to not regulate the field of religion in education, the Ministry of Education asked a handful of experts to give opinions and thus provide the basis for solving the dilemma systematically and in accord with the Slovenian constitution and its cultural traditions. ${ }^{23}$ Subsequently, the Ministry of Education published the White Book on Education [Bela knjiga o vzgoji in izobraževanju] in 1995, which highlighted the 'starting point' concept and stressed the key goals of the school organisation and curriculum reforms. ${ }^{24} \mathrm{New}$ laws on education were later passed. Of course, various religious actors did not approve of the course established in the White Book. The result was the Education Act, which introduced 'the autonomy of the school space', with an explicit prohibition of religious (confessional) education.

19 | Ibid., Ivanc, 2015, p. 41.

20 | Črnič, Pogačnik, 2019, p. 120.

21 | The presence of religion in public schools was evident in the Church's demand to introduce Catholic confessional religious education 'from kindergarten to university'. At the beginning of the 1990s, this demand was made by Alojz Uran, who in 2004 succeeded Rode as archbishop; Smrke, Rakar, 2006, p. 14.

22 | The proposal of the Roman Catholic Church was that confessional religious education be introduced in public schools. It would not be a classical catechism; however, it would be under the competence of the Roman Catholic Church. One of the main arguments of the Church for introducing confessional religious education in public schools was the equation of religiosity with morality. The government proposal, on the other hand, was that, in accordance with the constitutional principle of state-church separation, the reasonable solution would be (1) to introduce knowledge about religions in the existing subjects; (2) to introduce private education, in which there is no obstacle to confessional subjects; and (3) to introduce a non-confessional subject about religions in public schools; ibid., pp. 21, 22.

23 | Črnič, Pogačnik, 2019, p. 120. The second expert group concluded that public schools are secular in Slovenia. Secular schools, which realise the constitutional separation of state and religious communities, have to be neutral in relation to worldviews. Such a worldview-neutral school is a school that does not force anyone to accept a particular worldview, while at the same time offering elements enabling everyone to build a worldview of their own choosing. Therefore, it is not the task of the public school to form Catholics, liberals, Protestants, or atheists. That can be done only by private schools, families, churches, and so on, not the public school, which has to be a space of unification based on shared fundamental values, providing cultural identity and social integrity to future generations and a space of learning about democratic behaviour, tolerance, and respect for those who think differently; ibid., p. 122.

24 | Kalin, Šteh, 2007, p. 157. 


\section{Educational system in Slovenia and its legal regulation}

Slovenia's national education system is structured into several levels: early childhood education and care (kindergarten, or vrtec'), primary education (primary school, or osnovna šola), secondary general education (gymnasium, or gimnazija) or secondary vocational education (secondary vocational school, or srednja poklična šola), post-secondary non-tertiary education (višja strukovna šola), and tertiary education (higher school and university, or visoka šola and univerza). ${ }^{25}$

Preschool education is aimed at children aged 11 months to six years or until the children start compulsory primary education. It is not compulsory. Parents decide whether to enrol their children in a kindergarten. Preschool education is provided by both public and private kindergartens. ${ }^{26}$ Children pursue preschool education in 1,165 administrative units. These are set up in 108 independent public kindergartens, 203 school-based kindergartens, and 96 private kindergartens. There are 5,313 classes in total. The vast majority of children (94.4\%) attend public kindergartens. ${ }^{27}$

Primary and lower secondary education is organised as a single-structure nineyear basic school attended by students aged six to 15 years. It is provided by public and private schools (fewer than $1 \%$ of Slovenian students attend private basic schools), as well as educational institutions for SEN children and adult education organisations. Basic school education is compulsory and state-funded as specified by the Constitution of the Republic of Slovenia. Basic schools are set up by local communities. A wide public network of basic schools provides all residents of Slovenia access to education. In the 2018/2019 school year, 187,854 students attended 772 basic schools and branches, as well as 58 specialised schools and special units of mainstream basic schools and institutions for SEN children. In total, over 19,000 teachers are employed in Slovenian basic education..$^{28}$

After nine years of compulsory basic education (theoretically at the age of 15), students may continue on to two- to five-year non-compulsory upper secondary education. In the 2018/2019 school year, there were 111 public upper secondary schools (organised in single upper secondary schools or school centres), six private upper secondary schools, and six educational institutions for SEN children. The system of upper secondary education is centralised; decisions about their foundation and financing, as well as agreements on and the distribution of education programs, are adopted at the national level. However, schools and teachers enjoy autonomy in determining teaching content, choosing teaching methods, and staffing and managing employment relationships. ${ }^{29}$

Early childhood education and care are regulated by the Pre-School Institutions Act ${ }^{30}$, elementary education is regulated by the Elementary School Act ${ }^{31}$, secondary education

25 | Ivanc, 2015, p. 139.

26 | Taštanoska, 2019, p. 19.

27 | Ibid., p. 21.

28 | Ibid., p. 25.

29 | Ibid., p. 29, 30.

$30 \mid$ Zakon o vrticih, Uradni list RS, no. 100/05 - officially consolidated text, 25/08, 98/09 IUZGK, 36/10, 62/10 - ZUPJS, 94/10 - ZIU, 40/12 - ZUJF, 14/15 - ZUUJFO, 55/17, 18/21.

31 | Zakon o osnovni šoli, Uradni list no. 81/06 - officially consolidated text, 102/07, 107/10, 87/11, 40/12 - ZUJF, 63/13 in 46/16 - ZOFVI-L. 
is regulated by the Gimnazije $A c t^{32}$ and Vocational Education Act, ${ }^{33}$ and higher education is regulated by the Higher Education Act. ${ }^{34}$ Most important for this study's discussion is the Education Act, which explicitly bans religious education from public schools and kindergartens. The Education Act lists autonomy as one of the goals of child rearing and education. Under the Act, this concern for autonomy is manifest in extracurricular " types and varieties of knowledge and persuasion", and by ensuring the optimal development of individuals irrespective of their religious belief'. Accordingly, the Act requires that schools be religiously neutral and autonomous in religious communities. Additionally, this principle of autonomy prohibits discrimination against religious beliefs and urges principled tolerance. ${ }^{35}$

\section{Slovene state-church model}

In theory (and practice), three general models of church-state relations have been identified: 1 . the state or national church model; 2. the cooperative or concordant model; and 3. the strict church-state separation model (or separation model). ${ }^{36}$

Of course, these three models are not 'pure' models. They can be elaborated and combined into six models of church-state relations: 1 . aggressive animosity between the church and state (e.g. communist regimes), 2. strict separation in theory and practice (e.g. France); 3. strict separation in theory but not in practice (e.g. United States), 4. separation and cooperation (e.g. France, Germany); 5. formal unity but with substantial divisions (e.g. United Kingdom, Denmark, Israel, Norway); and 6. formal and substantial unity (e.g. Iran, Saudi Arabia). ${ }^{37}$

The Slovenian model of relations between the state and church is established by Article 7 of the Constitution. In Slovenian legal theory, the equality of religious communities has been, at least until the end of the first half of 2000, understood by the state as an 'undiscriminating affirmation of the whole religious field'. ${ }^{38}$ The meaning of this is that different religious communities are equal before the law. Some have said that the Slovene model of state-church relation can be called a 'model of separation with simultaneous cooperation' (model ločitve ob hkratnem sodelovanju). ${ }^{39}$ Religious communities are not part of the system of the separation of powers under Article 3 of the Constitution or of state institutions stricto sensu. However, as believers are citizens with the right to vote, the limitations on religious communities are derived from Article 7: Religious communities are not allowed to organize themselves as political

32 | Zakon o gimnazijah, Uradni list no. 1/07 - officially consolidated text, 68/17, 6/18 - ZIO-1, 46/19. 33 | Zakon o pokličnih in strokovnem izobraževanju, Uradni list no. 79/06, 68/17, 46/19; regarding secondary education one should also mention the Matura Examination Act (Zakon o maturi), Uradni list no. 1/07 - officially consolidated text in 46/16 - ZOFVI-L.

34 | Zakon o visokem šolstvu, Uradni list no. 32/12 - officially consolidated text, 40/12 - ZUJF, 57/12 - ZPCP-2D, 109/12, 85/14, 75/16, 61/17 - ZUPŠ, 65/17, 175/20 - ZIUOPDVE, 57/21 - decision of the Constitutional Court.

35 | Šturm. 2004., p. 626.

36 | Sokol, Staničić, 2014, p. 44.

37 | Ibid., p. 44; Brugger, 2007, p. 31.

38 | Črnič, Lesjak, 2003, p. 362; Dragoš, 2001, p. 41.

39 | Avbelj, 2019, commentary on Article 7. 
parties or act within state institutions. ${ }^{40}$ On the other hand, some feel that Slovenia follows the French model of laicite and that the principle of separation establishes a secular ${ }^{41}$ state. This means that the state must not be tied to any church and cannot privilege, discriminate against, or opt for religiosity or non-religiosity. ${ }^{42}$ Kaučić wrote that, in Slovenian legal theory and practice, the principle of separation between state and religious communities is largely understood and interpreted in terms of consistent and strict separation modelled on states with a more pronounced separation of state and church. Such a position is not to be attributed to the constitutional order, but to legal and executive derivations of this constitutional principle, particularly the influence of the previous political system. ${ }^{43}$

Slovenian authors agree that Article 7 of the Constitution sets forth three principles that define the legal position of religious communities in Slovenia: separation, the free action of religious communities, and the equality of religious communities. ${ }^{44}$ However, in accordance with Article 5 of the Constitution, the Religious Freedom Act regulates the duty of the state to respect the identity of religious communities and to maintain an open and continuous dialogue with them while developing forms of permanent cooperation. The principle of separation does not prevent religious communities from freely pursuing activities in their spheres. If the activities of the state and religious communities collide, their competence should be delimited according to the internal sovereignty of the state, which allows it to determine the proper limits but without preventing religious communities from pursuing social activities. ${ }^{45}$ Stres concludes that the principle of separation requires, in the spirit of European political culture, only that authorities not use religion for their own purposes and that religious organisations not attempt to abuse the state to achieve its own objectives. ${ }^{46}$

In 2007, Slovenia's parliament passed the Religious Freedom Act, ${ }^{47}$ by a majority of one (46 out of 90). ${ }^{48}$ The impact of this law on the Slovenian model of state-church relations was huge, as it marked a sharp change in practice and legislation. Prior to its enactment, Slovenia had been rightly portrayed as a country that mirrored France's laicite model of state-church relations, which is based on state neutrality. The law was a huge change because it embraced a different model of state-church relations - a cooperation model in which state neutrality does not have the same significance it had in the earlier model. The Religious Freedom Act obliges the state to enter relations with various religious communities. However, the Slovenian state did this prior to the law (having signed three agreements in the early 2000s), which would suggest that the model of state-church relations in Slovenia was never really that of laicite.

40 | Ibid.

41 | Naglič uses the term laičnost or laicite in French; see Naglič, 2017, p. 16.

42 | Ibid.

43 | Kaučić, 2002, p. 404.

44 | Mihelič, 2015, p. 132; Naglič, 2010, 4, pp. 491-492; see also decision U-I-92/07.

45 | Ivanc, 2015, p. 47.

46 | Stres, 2010, p. 492.

47 | Uradni list, no. 14/07, 46/10, 40/12,100/13.

48 Lesjak and Lekic claim that the Act was passed due to the votes of Italian and Hungarian minorities; see Lesjak and Lekić, 2013, p. 158. 


\section{Religious education in public schools in Slovenia}

No religious education is offered in Slovenian public schools, stricto sensu. As discussed above, the Slovenian model of state-church relations emphasised state neutrality and resembled the French laicite model. However (as mentioned), this model was modified extensively in 2007 via the Freedom of Religion Act, which introduced a cooperation model of state-church relations. The state signed various agreements with religious communities in the 2000s. ${ }^{49}$ Slovenia had strongly emphasized state neutrality, especially in the 1990s, and thus opted for a very strict (Ivanc calls it 'ultra-strict') approach to religious education in public schools. Unlike other former Yugoslav republics, which all reintroduced religious (confessional) education after 1991, Slovenia went its own way after religious education was omitted from the school curriculum in 1951/1952. ${ }^{50}$ According to Ivanc, Slovenian legislators not only embraced the French idea of the secular school (l'école laïque) as well as the American model, but surpassed them by introducing an ultra-strict model of the separation between religion and the state/school, which is quite different from that of most European countries, whose laws guarantee religious instruction within the framework of the public school system..$^{51}$

The Education Act explicitly prohibits religious activities in public schools. It also prohibits any other kind of denominational activity in public schools and kindergartens. It was enacted in 1996 and established the 'autonomy of schools'. The state assumed an obligation to maintain neutrality and tolerance and conduct activities that are non-indoctrinating and non-proselytizing. The law forbids religious activities in public schools, which thus disallows 1. performing confessional religious education in the classroom; 2. having teaching content or teachers appointed by religious communities, and 3. organising religious services in school. ${ }^{52}$

This is all prescribed by Article 72 or the Education Act, as follows:

Article $72^{53}$

(Autonomous Use of School properties)

Activities not related to education may be carried out in public preschool institutions or schools with the permission of principals.

49 | 1. Treaty on legal issues between the Republic of Slovenia and the Holy See, signed on 14 December 2001, ratified in 2004, Uradni list RS-MP, no. 4/04.

1. The Agreement between the Slovenian Bishop's Conference and the Government of the Republic of Slovenia on Spiritual Care for Military Persons in the Slovenian Army (signed 21 September 2000), 2. The Agreement between the Evangelical Church in the Republic of Slovenia and the Government of the Republic of Slovenia on Spiritual Care for Military Persons in the Slovenian Army (signed on 20 October 2000),

3. The Agreement on Legal Status of the Pentecostal Church in the Republic of Slovenia (signed on 17 March 2004), The Agreement on Legal Status of the Serbian Orthodox Church (signed on 9 July 2004), 4. The Agreement on Legal Status of the Islamic Community in the Republic of Slovenia (signed on July 9, 2007),

5. The Agreement on the Legal Status of the Buddhist Congregation Dharmaling (signed on July 4 , 2008); see Ivanc, 2015, pp. 44, 45.

50 | Ibid., p. 147.

51 | Ivanc, 2011, p. 4.

52 | Marinović Bobinac, 2007, p. 435.

53 | Original text from 1996. 
Activities of political parties and their youth are prohibited in preschool institutions and schools.

Religious activities shall not be permitted in public preschool institutions, schools, preschool institutions, and schools with concessions.

Religious activities of the preceding paragraph of this Article shall include:

- sectarian Bible study or religious education aimed at establishing religion;

- instruction in cases where educational contents, textbooks, teacher training, and suitable characteristics of teachers are determined by religious communities;

- Organised religious rituals

Upon the proposal of a principal, the minister can exceptionally permit a Bible study or religious education to take place in a public preschool institution, school, preschool institution, or school with a concession outside class and after regular hours, if there are no other premises suitable for such activity in that local community.

Authorised state officials - with the exception of inspectorates and the state auditing agency - need the principal's permission to perform their duty in a preschool institution or school. An official may enter the premises of a preschool institution or school without the principal's permission if so authorised by law or a court decree or if that is unavoidable in order to make an arrest or protect people and property. ${ }^{54}$

In the case of Mihael et al. No. U-I-68/98 (November 2001), the Constitutional Court reviewed the question of whether the provisions of the Education Act interfered with the positive aspects of the freedom of religion, the principle of equality, the rights of parents, and the right to free education. The Court first declared that the general prohibition against denominational activities in public schools was not inconsistent with the Constitution and the European Convention. The only inconsistency with the Constitution was the prohibition against denominational activities in licenced kindergartens and private schools concerning denominational activities occurring outside the scope of the execution of a valid public program financed from state funds. ${ }^{55}$ The Court instructed the National Assembly to remedy that inconsistency within one year, and legislators changed the provision of Article 72 of the Education Act to allow licenced kindergartens and schools to carry out denominational activities outside the scope of the execution of a public service. ${ }^{56}$

This Constitutional Court decision needs to be analysed, as it is very important for the regulation of religious education in Slovenia. The Education Act was challenged before the Constitutional Court in 1998. ${ }^{57}$ "The petitioners challenged Art. 72.3 and 4 of the Organization and Financing of Upbringing and Education Act (hereinafter ZOFVI), according to which denominational activities are not permitted in public kindergartens and schools and licensed kindergartens and schools. As these provisions limited the carrying out of denominational activities to the private sphere of life and, in particular, prohibited denominational activities also in licensed private schools, outside the lessons considered to constitute a valid public program, they were allegedly inconsistent with Art. 41 of the

54 | Original text from 1996. English translation available at: http://www.unesco.org/education/ edurights/media/docs/a36b2378af3f193c33cdfc3eb7044b55d326c81e.pdf

55 | Ivanc, 2011, p. 462.

56 | Ibid.

57 | I am using the English translation of the decision, available at: http://www.us-rs.si/documents/ ea/8a/u-i-68-98-an2.pdf. 
Constitution and Art. 2 of the Protocol to the Convention for the Protection of Human Rights and Fundamental Freedoms (hereinafter EKČP or the Protocol to EKČP). ${ }^{58}$

The challenged provisions were allegedly also inconsistent with Art. 2 of ZOFVI, which includes among the goals of the system of upbringing and education the ensuring of the optimal development of the individual irrespective of their religion and an education emphasizing mutual tolerance, respect for differences and cooperation with other people. The petitioners suggested the annulment of the challenged provisions (point 1).

According to the Constitutional Court, ZOFVI is part of the school legislation adopted at the beginning of 1996. It represents the basis for the new system of regulations on upbringing and education that were conditioned by the social changes in Slovenia after the adoption of the Constitution in 1991. It regulates relations between the public and private school systems, the internal organization of schools and their financing, which equally apply to kindergartens, primary schools and (secondary) grammar and technical schools (hereinafter kindergartens and schools) (point 7.) ZOFVI regulates only the organization and financing of schools that carry out valid public programs, i.e. programs which enable the obtaining of a valid public diploma. Such schools can be public, licensed or private. Public and licensed kindergartens and schools are included in the public school network; ZOFVI considers private kindergartens and schools to be supplemental to the public school system. To ensure horizontal and vertical transition between public and private schools, ZOFVI contains provisions that ensure the comparable quality of public and private schools (the procedure for the adoption of programs, the monitoring of new programs, the examination of knowledge at the end of educational terms, standards for ensuring both material resources for work and the comparable education and salaries of educators and teachers).... The position of licensed schools is equal to the position of public schools in the part in which they carry out the public service: they carry out an educational program equal to that determined for public schools (Art. 15); for the entire educational program and not only for mandatory subjects, as applicable to private schools, they use mandatory textbooks and teaching requisites confirmed by the competent council of experts (Art. 21); they must be internally organized in this manner as public schools are (administrative bodies, a counseling service, a library - Arts. 46 to 68). Their financing is ensured in the same manner (Art. 85 in conjunction with Art. 77). They are not granted only $85 \%$ of the funds per student the State or the local community ensures

58| The Constitution and EKČP allegedly ensure the freedom to profess a religion on school premises. The provisions allegedly prevented parents from exercising at school the right to provide their children with a religious and moral upbringing in accordance with their beliefs (Art. 41.3 of the Constitution). A private school is not allegedly an equivalent alternative to a licensed school, since only $85 \%$ of its activities are financed from public funds; if the existence of a public school is threatened, such funds are allegedly to be withdrawn pursuant to Art. 87 of ZOFVI. For these reasons, the provisions were allegedly contrary to the prohibition against discrimination on the basis of religious beliefs (Art. 14 of the Constitution and Art. 14 of EKČP). The challenged provisions also allegedly interfered with vested rights. The private schools which were granted a license on the basis of the previously valid Financing of Upbringing and Education Act (Official Gazette RS, No. 12/91; 'ZOFVI91' hereafter), will allegedly lose their licenses due to the challenged ZOFVI provisions if they do not discontinue the religious lessons provided in their curriculum. Para. 4.2, in conjunction with Art. 72.3, of ZOFVI was also contrary to the principle of equality before the law (Art. 14 of the Constitution), as it allegedly prevented religious communities from applying for a license. In contrast to the case of other founders of schools and kindergartens, it allegedly prevented religious communities from deciding on the substance, textbooks, teacher education, and teacher suitability. 
for salaries and material expenses in public schools, as determined for private schools, but the financing of the activities they carry out as a public service is fully provided from public funds (point 8).

The court interpreted the challenged provisions in a manner that they prohibit the types of denominational activities determined in Art. 72.4 of ZOFVI from being part of a program carried out as a public service on the premises of public and licensed kindergartens and schools, and also prohibited such activities from being carried out outside the extent of such a program on the premises of public and licensed kindergartens and schools (point 10).

It reiterated that, in the framework of freedom of religion, the Constitution ensures parents the right to provide their children with a religious upbringing in accordance with their beliefs (Art. 41.3 of the Constitution). These constitutional rights of parents oblige the State to respect their religious beliefs also in the field of schooling. The duty of the state to respect the religious beliefs of parents in the field of schooling also follows from Art. 26.3 of the Universal Declaration of Human Rights ('Declaration' hereafter), which provides that parents have the right to decide on the education of their children, and from the second sentence of Art. 2 of Protocol No. 1 to the EKČP. This provides that, in carrying out its tasks in the area of upbringing and education, the State must respect the right of parents to provide their children with a religious upbringing in accordance with their religious (and philosophical) beliefs (point 14).

In the case at issue the positive aspect of the freedom of conscience of those (Art. 41.1 of the Constitution) who want to profess their religion through denominational activities in a public school or public kindergarten or a licensed school or kindergarten and the right of parents to provide their children with a religious upbringing in accordance with their religion (Art. 41.3 of the Constitution) come into conflict with the negative freedom of conscience of those who do not want to profess their religion (Art. 41.2 of the Constitution). The Constitutional Court will have to review whether Art. 72 of ZOFVI is inconsistent with the constitution in its prohibition of denominational activities outside the scope of a public service (point 15).

In this case the legislature interfered with the positive aspect of freedom of religion (Art. 41.1 of the Constitution) and the right of parents determined in Art. 41.3 of the Constitution to protect the negative aspect of the freedom of religion of other children and their parents (Art. 41.2 of the Constitution). To achieve this goal, interference with the right determined in Art. 41.1 of the Constitution was necessary. According to Art. 41.2 of the Constitution, citizens have the right not to declare their religious beliefs and to require that the State prevent any forced confrontation of the individual with any kind of religious belief. A democratic State (Art. 1 of the Constitution) is, on the basis of the separation of the State and the Church (Art. 7 of the Constitution), obliged in providing public services and in public institutions to ensure its neutrality and prevent one religion or philosophical belief from prevailing over another, since no one has the right to require that the State support them in the professing of their religion. To reach this goal it is constitutionally admissible that the State takes such statutory measures as are necessary to protect the negative aspect of freedom of religion and thereby realize the obligation of neutrality (point 17).

Furthermore, the interference with the positive aspect of freedom of religion cannot be considered inappropriate as thereby the forced confrontation of non-religious persons or persons of other denominations with a religion they do not belong to can be 
prevented. This interference is also proportionate, in the narrow sense of the word, in so far as it relates to the prohibition of denominational activities in public kindergartens and schools. These are namely public (State) institutions financed by the State and are as such the symbols which represent the State externally and which make the individual aware of it. Therefore, it is legitimate that the principle of the separation of the State and religious communities and thereby the neutrality of the State be in this context extremely consistently and strictly implemented (point 18).

However, the interference with the positive freedom of religion and the rights of parents determined in Art. 41.3 of the Constitution is not proportionate in the narrow sense of the word in the part relating to licensed kindergartens and schools outside the scope of performing a public service. In this respect the adjective "public" does not refer to an institution as a premises, nor does it refer to an entire activity, but only to that part of the activity that the State finances for carrying out a valid public program. The principle of democracy (Art. 1 of the Constitution), the freedom of the activities of religious communities (Art. 7.2 of the Constitution), the positive aspect of freedom of religion (Art. 41.1 of the Constitution), and the right of parents to bring up their children in accordance with their personal religious beliefs (Art. 41.3 of the Constitution), impose on the State the obligation to permit (not force, foster, support or even prescribe as mandatory) denominational activities on the premises of licensed kindergartens and schools outside the scope of the execution of a valid public program financed from State funds. This is all the more so as there are milder measures that ensure the negative aspect of the freedom of religion. In reviewing proportionality in the narrow sense we must weigh in a concrete case the protection of the negative aspect of the freedom of religion (or freedom of conscience) of non-believers or the followers of other religions on one hand against the weight of the consequences ensuing from an interference with the positive aspect of freedom of religion and the rights of parents determined in Art. 41.3 of the Constitution on the other. There is no such proportionality if we generally prohibit any denominational activity in a licensed kindergarten and school. By such prohibition the legislature respected only the negative freedom of religion, although its protection, despite the establishment of certain positive religious freedoms and the rights of parents to provide their children a religious upbringing, could as well be achieved by a milder measure (point 19)."

With amendments made based on the decision of the Constitutional Court, Article 72 of the Education Act now reads as follows:

“Article 72

(Autonomy of School Premises)

Activities not related to education may take place at a public kindergarten or school only with the permission of the head teacher.

At kindergartens and schools, all activities of political parties and their youth sections shall be prohibited. At public kindergartens and schools, confessional activity may not be allowed. At kindergartens and schools holding a concession, confessional activity shall be allowed if it takes place outside the programme implemented as a public service. Confessional activity shall be allowed at kindergartens and schools holding a concession if it does not, in terms of time and space, interfere with the programme implemented as a public service. Confessional activities shall be organised so as to allow those who do not wish to participate to attend or leave freely. The confessional activity referred to in the previous paragraph of this Article shall encompass: - Catechesis or the confessional teaching of religion with the goal of inculcating this religion; 
- Courses where a religious community decides on the content, textbooks, teacher education and adequacy of individual teachers for teaching;

- Organised religious ceremonies.

Upon the head teacher's proposal, the Minister may exceptionally allow catechesis or confessional teaching of religion on the premises of a public kindergarten or school outside instruction or working hours if there is no other suitable venue in the local community for such activity.

The head teacher's permission shall be required to pursue the activities of authorised government bodies in a kindergarten or school, except for the activities of inspection bodies and the Court of Audit.

An official may enter a kindergarten or school without the head teacher's permission if the official is authorised to do so by law or by order of competent court, or if this is absolutely necessary to directly apprehend a person who has committed a criminal offence, or to protect people and property. ${ }^{\text {"59 }}$

The Constitutional Court approved the ban on 'confessional activities' because of the strong emphasis on state neutrality prescribed by Article 7 of the Constitution. According to Stres, confessional activity encompasses the following: religious or confessional instruction aimed at educating for a particular religion; and lesson content, textbooks, teacher education, and criteria of teacher suitability decided by a religious community or organised religious rites. ${ }^{60}$ In this way, the presence of religion is completely expelled from a public space: the school. It is true that Article 72, para 5 of the Education Act provides for an exemption from this strict rule. The minister may allow, exceptionally, catechesis or confessional teaching of religion on the premises of a public kindergarten or school outside instruction or working hours if there is no other venue in the local community suitable for such activity. A public school may not have the space or facilities required (e.g. because of a large number of pupils, a natural disaster, a fire) and may use church premises for public education. However, restrictions are placed on this exception. ${ }^{61}$ Therefore, the court took the path by which, according to Šturm, it placed the Republic of Slovenia on the extreme edge among European countries with a doctrine described as an unfriendly or intolerant model of separation. ${ }^{62}$ This decision was strongly criticised by Ivanc, who wrote that it has several deficiencies. ${ }^{63}$ First, the court used a different criterion for judicial review of the contested provision of the Education Act. Second, the court failed to examine the complex nature of different measures that impose limitations on the constitutional right to freedom of beliefs, conviction, and religion. ${ }^{64}$ Ivanc

59 | Unofficial translation to English by the Ministry of Education, Science and Sport of the Republic of Slovenia (2017), available at: https://zakonodaja.sio.si/wp-content/uploads/sites/10/2011/08/ OFEA_npb_170605.pdf

60 | Stres, 2010, p. 491.

61 | Stres mentions an interesting example showing that this removal of religion from schools goes to an extreme. In one case, a school was undergoing renovations, and education was taking place on church premises. There was a cross on the wall and the pastor (župnik) refused to remove it. Education was discontinued in that space; ibid., p. 491. Šturm and Ivanc also state that, while legislation does not explicitly prohibit or allow the display of a crucifix or a cross in schools, these symbols are prohibited in practice as they violate the principle of separation. Šturm, Ivanc, 2019, p. 552.

62 | Šturm, 2002, p. 139.

63 | Ivanc, 2015., p. 149.

64 | Ibid. 
finds that the court's doctrines supporting its argumentation are incoherent. The court's conclusion that the doctrine of state neutrality rules out the presence of religion in the public sphere, especially in the field of education, is doubtful in a democratic and pluralistic Slovene state. ${ }^{65}$ Furthermore, Ivanc stresses that one can hardly say that the court's decision in this case provided for an appropriate protection of the positive aspects of religious freedom in public schools, with the exception of Article 72 Para. 5, according to which, when denominational activities cannot be carried out in a local community, they may take place on the premises of a public school. ${ }^{66}$

One should also bear in mind that this decision was handed down in 2001 and that the Education Act was enacted in 1996. The emphasis on state neutrality was significantly stronger then, as can be seen from decision U-I-92/07 of the Constitutional Court. In this decision on the constitutionality of the Religious Freedom Act, the court ruled that negative freedom has no a priori advantage over positive freedom in the conflict between positive and negative freedom of religion (i.e. when positive freedom of religion interferes with negative freedom of religion). This means that the right of unbelievers not to be confronted with a religious belief and religious symbols does not always and automatically take precedence over positive religious freedom, which is the freedom of believers to profess their faith and to testify it publicly. ${ }^{67}$ The main significance of the Religious Freedom Act for the Slovene state-church model, as discussed above, was that it shifted Slovenia towards the cooperation model.

\section{| 5.1. Financing of private schools and religious education}

The question of public funding for private schools is a very interesting question concerning religious education. This issue is hotly disputed in Slovenia. There was an initiative, in November 2017, to amend Article 57 of the Constitution, which prescribes freedom of education and decrees that primary education is compulsory and shall be financed from public funds (and that the state must create opportunities for citizens to obtain a proper education). The Social Democrats (Socialni Demokrati) proposed amending the article in order to ensure that only public schools receive public funding. There were 60 votes in favour and 22 votes against (out of 90 members of the National Assembly). However, the constitutionally prescribed majority of two-thirds was not achieved, so Article 57 remained unchanged. Several parliamentary parties were strongly opposed, such as the Slovenian Democratic Party (Slovenska demokratska stranka) and New Slovenia (Nova Slovenija - kršćanski demokrati), who argued that the initiative was motivated by ideology. ${ }^{68}$

It is necessary to mention two other decisions of the Constitutional Court: U-I-269/12 of December 4, 2014, ${ }^{69}$ and the subsequent decision U-I-110/16 of March 12, 2020.70 In decision U-I-269/12, the Constitutional Court found the first sentence of the second paragraph

65 | Ibid., p. 152.

66 | Ibid., p. 153.

$67 \mid$ Stres, 2010, p. 492

68 | https://www.total-slovenia-news.com/politics/157-public-funding-of-private-education https://sloveniatimes.com/controversial-bill-changing-private-primary-school-financingpassed/ (Acceesed: 20.10.2021).

69 | Uradni list RS no. 2/15.

70 | Uradni list RS no. 47/20. 
of Article $86^{71}$ of the Education Act not in accordance with the constitution. The court gave the National Assembly one year to rectify the situation (i.e. to amend the Education Act). The problem that arose concerned the financing of private (religious) schools. The Education Act prescribes that the state shall fund $85 \%$ of the costs of private schools that provide officially recognised programs of basic education, basic music education, upper secondary vocational and technical education, or gimnazije. The government's response made it clear that it believed it essential that private school programs include contents that public schools do not or may not include in their programs, such as confessional activities (point 24). The court concluded that such an intention was not valid, and that the contents of the compulsory primary education programs funded by public funds must be uniform for all providers of primary education. The state does not finance content that depends on the value orientations of individual providers of primary education (point 25). The outcome of this decision should have been the full funding of private schools or equal funding between private and public schools. However, the National Assembly did not act in accordance with the decision of the Court for more than five years. In 2016, a group of petitioners went before the Constitutional Court to try to force the government to enforce the 2014 decision. However, the court, in a somewhat Copernican twist, ruled that the parts of the contested provision relating to the public funding of supplementary education, morning care, and extended stay in a private primary school providing an officially recognised program are in accordance with the constitution. The court said that it first had to answer the question of whether the earlier decision referred only to the public financing of the compulsory part of primary education or to the public financing of the entire primary education program. The Constitutional Court emphasised that Decision No. U-I-269/12 found the challenged provision to be inconsistent with the constitution only in terms of the public financing of state-approved private primary school programs that correspond to the content of the compulsory part of the primary education program in public schools. It stated that the legislator has a wide margin of discretion and that the scope of this right may be adjusted over time, taking into account the needs and assets of society and individuals. However, the legislator must comply with the constitutionally protected core of the right to education and schooling (Article 57 of the Constitution; point 24). Therefore, the question arises as to whether students should, to fulfil the obligation of primary education in a private school, attend the entire program of primary education or only part of it. The court found that the extended part of the program of a private primary school does not correspond to the program of public primary schools and is not compulsory. This means that the constitutional obligation of primary school education in a private school providing officially recognised programs refers only to the program contents corresponding to the contents of the compulsory work in a program of public primary schools (point 27). Therefore, only that part of the private school program should receive $100 \%$ of public funding. The court tried to explain its view with reference to the earlier decision from 2014, stating that it assessed only the constitutionality of Article 86 (in the contested part) concerning the mandatory fulfilment of the constitutional obligation of primary education. It stated that it never held that the extended and compulsory parts of the primary school curriculum form an indivisible whole (point 31). If they did form an indivisible whole, then public funding would have to cover the whole curriculum,

71 |'Private schools that provide the programmes as specified under paragraph 1 of this Article shall receive for the implementation of the programme $85 \%$ of funds allocated by the state or local community to the implementation of the public school programme'. 
which the petitioners argued is what the court had asserted in points 25,26 , and 27 of the earlier decision.

In the aftermath of these decisions, the National Assembly amended the Education Act in June 2021. ${ }^{72}$ This amendment was preceded by an extensive public debate about necessary changes to the act. The amended Article 86 prescribes that private schools receive $85 \%$ of the funds provided by the state or local community for the implementation of the public school program. However, in addition to that $85 \%$, a private school providing officially recognised programs should be funded from the state budget or the local budget for the implementation of the compulsory part of the officially recognised program at a rate of up to $100 \%$ of the public school level. Therefore, private schools are underfunded (15\%) for morning care, extended stays, and other programs.

The state clearly does not want to fund any part of the curricula that differs from the curricula used in public schools. One could even say that the full funding of private schools is opposed due to the ideological fear of religion because the state would have to fund the religious parts of approved curricula in private schools.

\section{| 5.2. Elements of religious education in Slovene public schools}

Although there is no religious education in Slovenia's public schools, elements of it appear in other subjects. For example, religious facts are part of the history, philosophy, literature, arts, and language curricula. ${ }^{73}$

Slovenian schools teach two courses: Religion and Ethics and Civic Patriotic Education and Ethics. The former is facultative ${ }^{74}$ and non-confessional, and a pupil may take it in the last three years of primary school; the latter is compulsory and is offered in the $7^{\text {th }}$ or $8^{\text {th }}$ year of grammar school. Religion and Ethics is also an optional subject in upper secondary education. ${ }^{75}$ Marinović Bobinac states that the syllabus for Religion and Ethics was prepared by a team of expert philosophers, sociologists, theologians (both Catholic and Evangelical), and educational experts. ${ }^{76}$ However, Ivanc states that neither subject

72 | Zakon o spremembi Zakona o organizaciji in financiranju vzgoje in izobraževanja, Uradni list RS no. 123/21.

73 | Ivanc, 2015, p. 155.

74 | Slovene authors call it a 'compulsory-optional' subject, since the schools are obliged to offer it, and the students are free to choose it. It is an ordinary school subject. Everything concerning this subject (the training of the teachers as well as the preparation of the educational programs and textbooks) is under the competence of the responsible state institutions, as in the case of all other school matters. Neither the Catholic Church, as the largest religious community in Slovenia, nor other religious communities have any exclusive competence over this subject; Smrke, Rakar, 2006, p. 26. 75 | Ivanc, 2015, p. 155.

76 | Marinović Bobinac, 2007, p. 435; the author states that it is taught for three years, in the 7th, 8th, and 9 th grades (ages 13 to 15), and the program respects three fundamental principles:

1. religious contents are divided into three units, each of which is internally coherent

2. the approach used for religious issues in every grade is appropriate for the ages and cognitive development of the students

3. the ethical and existential issues to be discussed are chosen according to the needs of the students The themes (i.e. contents) are chosen according to two criteria:

a) they are relevant for both a holistic and analytic knowledge of religions and are covered in such a way as to connect to the experiences and questions in the students' physical and contemplative world, or are directed to them ('religiological themes');

b) they appear in the students' physical and contemplative world, the elaboration of which requires and displays connections to religions and non-religious worldviews ('life themes'); ibid., p. 436. 
was implemented successfully, and some argue that few Slovenian secondary school students receive a systematic religious education. ${ }^{77}$

\section{| 5.3. Religious education in private schools}

Private schools have been allowed in Slovenia since 1991. There are no obstacles to religious education in private schools, as was stressed by the Constitutional Court. Private schools are free to decide whether to introduce religious education. ${ }^{78}$ According to Ivanc, only two private primary schools (one established by the Catholic Church and one by a private person) provide denominational religious education. Among Slovenia's upper secondary schools, religious education is offered in only four Catholic schools. ${ }^{79}$

\section{Conclusion}

It is obvious that Slovenia chose an approach to religious education in public schools (and initially, in 1996, even private schools) that differed from that taken by all other exYugoslav republics. Those republics reintroduced religious (confessional) education in public schools and opted for the cooperation model. By contrast, Slovenia opted for an extreme (or 'ultra strict', as Ivanc calls it) approach to religious education in public schools, introducing a strict separation model of religion-state/school relations. This approach is, I would argue, unusual by European standards, as religious education is offered in almost all European countries.

This education is mostly confessional, with some countries opting for education in religious culture. Slovenia is a member of a relatively small group of countries, along with France (with some exceptions in historical regions) and Albania, which do not offer religious education. As mentioned, Slovenia introduced some elements of religious education through other courses, and Religion and Ethics is offered as an optional course. However, there were (are) problems with that course's implementation, and Ivanc states that few secondary school students receive a systematic religious education. Therefore, it must be concluded that religious education in Slovenia is almost non-existent; Slovenia has always insisted on a strict separation of state and church, especially in the 1990s. However, the situation changed due to the Freedom of Religion Act. Therefore, it may be time to rethink the position of religious education in Slovene public schools. In 1999, Kodelja suggested that some obligatory courses ${ }^{80}$ on religion and ethics should be part of

77 | Ivanc, 2015, p. 155; Šverc, 2008, p. 245.

78 | See ibid., p. 145.

79 Ibid; in Catholic primary schools, Encountering Religion is offered in the first two academic years; in the third year, Religion and Culture is offered; in the fourth year, Religion and Culture is offered again.

80 | As obligatory subjects, Kodelja mentions world religions; Christianity, Islam, and Buddhism; religious culture, rites, symbols, and religious communities; religions and the problems of evil, sin, death and the direction of life; ethical prospects for religions; Christianity and Western civilization; the Bible (Old and New Testaments); Catholicism; Orthodoxy; Protestantism; the Enlightenment; Christianity in Slovenia; religions and the sense of life; and religious freedom and freedom of conscience; Kodelja, 1999, pp.155-156. 
school curricula, as well as some optional courses. ${ }^{81}$ It is impossible ${ }^{82}$ to introduce pupils to all the required topics through other subjects (e.g. history, arts), and only some pupils choose to take Religion and Ethics in Slovenia. This means that most pupils lack knowledge about, inter alia, major world religions, religious cultures, and religious freedom. For this reason, I argue that an obligatory course should be introduced in Slovene public schools. One could, and perhaps should, ask whether today's legal regulation on religious education enables the development of a pluralistic educational system. If there is no exploration of the vast topic of religion (not only confessional religion, but religion as a social construct and part of every society), how is it possible to ensure the existence of a pluralistic educational system in which all are equal and equally respected? The ECHR stated as follows in the Kokkinakis judgement:

[Freedom of religion is] one of the foundations of a democratic society. This freedom, in its religious dimension, is one of the most important elements that create the identity of believers and their conception of life, but it is also a precious tool of atheists, agnostics, sceptics and those who do not have any relation towards faith.

This view was reiterated in the now-famous judgement Bayatyan v. Armenia (2011), in which the court stated that 'freedom of religion is one of the foundations of a democratic society. The pluralism indissociable from a democratic society ... depends on it'. In addition, in Manoussakis and Others v. Greece (1996) and Metropolitan Church of Bessarabia and Others v. Moldova (2001), the court stated that freedom of religion is 'necessary to maintain true religious pluralism, which is vital to the survival of a democratic society'. When we accept that religious education (and the right to it) is a part of freedom of religion, we must acknowledge that today's legal regulation on religious education does not enable the development of a pluralistic educational system.

Confessional education may be a step too far for Slovenia, but religious education in the form of courses on religious culture would be a welcome addition to school curricula in Slovenia.

81 | For example, Judaism, Taoism, churches, sects and monastic communities, relations between church and state, religious tolerance; ibid.

82 I Some Slovene authors do not share this opinion and feel that non-confessional teaching about religions is beneficial and is an important part of general education. They feel that there are two ways of teaching about religions in public schools: first, as a part of some other compulsory subject, especially Ethics and Society or other subjects such as History and Literature; and, second, through Religions and Ethics; Smrke, Rakar, 2006, p. 25. 


\section{Bibliography}

Avbelj, M. (ed.) (2019) Komentar Ustave Republike Slovenije - Del 1: Človekove pravice in temeljne svoboščine, Nova univerza, Europska pravna fakulteta. 2019.

Brugger, W. (2007) 'On the Relationship between Structural Norms and Constitutional Rights in Church-State-Relations' in Brugger, W., Karayanni, M. (eds.) Religion in the Public Sphere: A Comparative Analysis of German, Israeli, American and International Law. Berlin: Springer.

Črnič, A. (2009) 'Cult versus Church Religiosity: Comparative Study of Hare Krishna Devotees and Catholics in Slovenia', Social Compass, (56)1, pp. 117-135.

Črnič, A., Komel, M., Smrke, M. (2013) 'Religious Pluralisation in Slovenia', Teorija in Praksa, 50(1) pp. 205-232.

Črnič, A., Lesjak, G. (2003) 'Religious Freedom and Control in Independent Slovenia', Sociology of Religion, 64(3), pp. 349-366.

Črnič, A., Pogačnik A. (2019) 'Religious Symbols in Public Schools: Key Issues and Debates', CEPS Journal, 9(4), pp. 109-127.

Dragoš, S. (2001) 'Cerkev/država: ločitev ali razločitev', in Hvala, I., (ed.) Država in cerkev: laična država kot jamsto. Ljubljana: Fakulteta za družbene vede.

Filipović, A. T. (2011) 'Der Religionsunterricht in öffentlichen Schulen in Europa Modelle und Entwicklungen als Indikatoren für die gesellschaftliche Bedeutung des Glaubens und die Anfrage an Theologie und Kirche', Nova Prisutnost, 9(1), pp-137-152.

Ivanc, B. (2011) 'Religion in Public Education - Slovenia', in Robbers, G. (ed.) Religion in Education. : European Consortium for Church and State Research

I Ivanc, B. (2015) Religion and Law in Slovenia. Croydon : Wolters Kluwer.

Ivanc, B., Šturm, L. (2015) 'Slovenia' in Encyclopedia of Law and Religion - Europe. Leiden-Boston: Brill, pp. 379-388.

Kalin, J., Šteh. B. (2007) 'Teachers Facing the Challenges of Daily Practice in a School Reform' in Burcher, J., McDonald, L. (eds.) Making a Difference: Challenges for Teachers, Teaching, and Teacher Education. Leiden: Sense Publishers

Kaučić, I. (2002) The Principles of Constitutional Regulation of Relation Between State and Church in Slovenia. Ljubljana: SAZU.

Kodelja, Z. (1999) 'The Teaching about Religion at Slovene Public Schools', The School Field, 10(3/4), pp.153-158.

Lesjak, G., Lekić D. (2013) ‘Država in verske skupnosti: kronika odnosov med letoma 2008 in 2011', Teorija in Praksa, 50(1), pp. 154-171.

Marinović Bobinac, A. 'Comparative Analysis of Curricula for Religious Education: Examples of Four Catholic Countries', Metodika 8(15), pp. 425-443. 
Mihelič, R. (2015) 'Posebej o pravnem statusu Katoliške cerkve v Sloveniji', Bogoslovni vestnik, 75(1), pp. 129-142.

| Naglič, A. (2017) ‘Svoboda cerkva v Sloveniji', Res Novae, 2(2), pp. 7-32.

Naglič, A. (2010) 'Svoboda vere v odločbi Ustavnega sodišča Republike Slovenije o ustavnosti zakona o verski svobodi', Bogoslovni Vestnik, 70(4), pp. 483-493.

Smrke, M., Rakar, T. (2006) 'Religious Education in Slovenia' in Kuburić, Z., Moe, K. (eds.) Religion and Pluralism in Education Comparative Approaches in the Western Balkans. Novi Sad: CEIR, pp. 9-38.

Sokol, T. Staničić, F. (2018) ‘Pravni položaj Katoličke Crkve kao gospodarskog subjekta u pravu Europske unije i hrvatskom pravu', Zbornik Pravnog Fakulteta u Zagrebu, 68(3-4), pp. 31-60.

Staničić, F. (2014) 'The Legal Status of Religious Communities in Croatian Law', Zbornik Pravnog Fakulteta u Zagrebu, 64(2), pp. 225-254.

Staničić, F. (2018) ‘Treba li nam revizija ugovora sa Svetom Stolicom?', Zbornik Pravnog fakulteta u Zagrebu, 68(3-4), pp. 397-429.

Stres, A. (2010) 'Sekularno društvo, laičnost i prisutnost vjerskih obilježja i simbola u Sloveniji', Riječki teološki časopis, 18(2), pp. 481-494.

Šverc, M. (2008), 'Predmet "Vjera i kultura" u katoličkim gimnazijama u Sloveniji', Kateheza, 30(3), pp. 245-255.

Taštanoska T. (ed.) (2019) The Education System in the Republic of Slovenia 2018/2019. Ljubljana: Ministry of Science, Education and Sport of the Republic of Slovenia.

Šturm, L. (2004) 'Church-State Relations and the Legal Status of Religious Communities in Slovenia', Brigham Young University Law Review. 607, pp. 607-650. .

Šturm, L., Ivanc, B. (2019) 'State and Church in Slovenia' in Robbers, G. (ed.) State and Church in the European Union.Baden-Baden : Nomos, pp. 539-561.

Šturm. L. (2002) Komentar Ustave Republike Slovenije. Ljubljana: Fakulteta za podiplomske državne in evropske študije. 